\title{
ANALISIS KEUNTUNGAN USAHATANI PADI SAWAH ORGANIK DI KECAMATAN MUARA BULIAN KABUPATEN BATANG HARI (Studi Kasus di Desa Pasar Terusan)
}

\author{
Salina ${ }^{1)}$, Edison ${ }^{2)}$, Emy Kernalis ${ }^{2)}$ \\ 1) Alumni Jurusan Agribisnis Program Studi Agribisnis Fakultas Pertanian Unja \\ ${ }^{2)}$ Staf Pengajar Jurusan Agribisnis Fakultas Pertanian Unja \\ Email: Salina.Lina@yahoo.co.id
}

\begin{abstract}
ABSTRAK
Penelitian ini bertujuan untuk mengetahui (1) besarnya keuntungan yang diperoleh petani dari usahatani padi sawah organik di Desa Pasar Terusan Kecamatan Muara Bulian Kabupaten Batang Hari (2) faktor-faktor yang mempengaruhi keuntungan usahatani padi sawah organik di Desa Pasar Terusan Kecamatan Muara Bulian Kabupaten Batang Hari. Metode analisis data yang digunakan dalam analisis ini adalah analisis Deskriftif Kuantitatif yaitu analisis keuntungan yang terdiri dari analisis penerimaan dan biaya produksi untuk usahatani padi sawah organik. Untuk menganalisis faktor-faktor yang mempengaruhi keuntungan usahatani padi sawah organik digunakan metode Analisis Regresi Linier Berganda. Penelitian ini dilaksanakan pada tanggal 01 Oktober 2015 sampai dengan 01 November 2015.

Hasil penelitian ini menunjukan (1) rata-rata keuntungan usahatani padi sawah organik di daerah penelitian sebesar Rp. 17.023.361/musim tanam dan rata-rata keuntungan usahatani padi sawah organik per hektar di daerah penelitian sebesar Rp. 22.182.569/ha/tahun. (2) Faktor luas lahan, biaya benih, biaya obat-obatan, dan biaya tenaga kerja berpengaruh secara nyata terhadap keuntungan usahatani padi sawah organik sehingga baik untuk ditingkatkan. Sedangkan faktor biaya pupuk tidak berpengaruh secara nyata terhadap keuntungan usahatani padi sawah organik, hal ini dikarenakan petani telah mengeluarkan biaya melebihi pada kisaran yang optimal. Dari hasil penelitian diharapkan adanya penyuluhan yang membangun terhadap petani padi sawah organik agar petani dapat memperoleh pengetahuan-pengetahuan yang lebih luas dalam mengelola usahataninya, sehingga dapat lebih meningkatkan keuntungan petani padi sawah organik.
\end{abstract}

Kata kunci : Keuntungan, Usahatani Padi Sawah Organik, dan Faktor Produksi

\section{ABSTRACT}

This research is to know: (1) the amount of profits earned by farmer from organic ricein Pasar Terusan village Muara Bulian district Batang Hari regency (2) the factors affecting the profits of the organic rice famers inPasar Terusan village Muara Bulian district Batang Hari regency. Data collected in this research is analyzed this data analize used methode used in quantitative descriptive method That is the advantage analysis consists of an analysis of the revenue and production costs for organic rice farming. To analyze the factors that affect the benefits of farming the organic rice used Multiple Linear regression analysis method. This research located in Pasar Terusan village Muara Bulian district Batang Hari regency in 01 October 2015 untill 01 November 2015.

The results of this research indicate (1) the average profits of farming of organic rice in the area of research is $\mathrm{Rp}$. 17.023.361/the planting season and the average profits of farming the organic rice per hectare in areas of research of Rp. 22.182.569/ha/year (2) Factors of land area, the cost of seed, the cost of drugs, and the cost of labor is influential in the real profits of farming the organic rice so well for enhanced. While the cost of fertilizer has no effect in the real profits of farming of organic rice, this is because the farmer have issued charges exceed the optimal range. From this research the expectation elucidation into the farm rice organic that knowledge acquire the biggest on farm application.

Keyword: Profits, farm Rice Organic, and Factor of production 


\section{PENDAHULUAN}

Salah satu upaya mengurangi penggunaan bahan kimiawi pada budidaya tanaman padi adalah dengan menerapkan pertanian secara organik. Pertanian organik dapat diartikan sebagai suatu sistem produksi pertanaman yang berasaskan daur ulang hara secara hayati (Sutanto, 2002). Pengertian lainnya mengenai pertanian organik adalah suatu sistem produksi pertanian yang menyeluruh dan terpadu, dengan cara mengoptimalkan kesehatan dan produktivitas agroekosistem secara alami sehingga menghasilkan pangan dan serat yang cukup, berkualitas, dan berkelanjutan (Tombe dan Hendra, 2010). Jadi pertanian organik merupakan suatu kegiatan proses produksi yang dilakukan secara alamiah tanpa dicampur dengan bahan-bahan kimia, sehingga tidak akan berdampak buruk terhadap kesehatan dan lingkungan.

Desa Pasar Terusan Kecamatan Muara Bulian Kabupaten Batang Hari merupakan salah satu desa yang mengusahakan padi sawah secara organik. Dengan petani menggunakan pupuk organik dan obat-obatan non kimia sebagai input usahataninya, petani berupaya untuk dapat membangun kesuburan tanah, menjaga ekosistem lingkungan, dan meningkatkan produktivitas tanaman dalam jangka panjang, dengan harapan dapat pula menekan biaya usahatani yang nantinya dapat meningkatkan pendapatan dan kesejahteraan bagi petani.

Berdasarkan data luas panen dan produksi padi sawah organik di Desa Pasar Terusan bahwa dari tahun 2010 sampai pada tahun 2013, terlihat bahwa rata-rata luas panen padi sawah organik sebesar 768,25 ha dengan produksi rata-rata sebesar 4.975 ton dan produktivitas rata-rata sebesar 6,45 Ton per ha.Apabila dilihat dari perkembangan luas panen dan produksi selama kurun waktu lima tahun terjadi peningkatan luas panen padi sawah sebesar 28,9 persen dan tingkat produksi sebesar 43,9 persen. Jumlah produksi padi sawah organik mengalami fluktuasi yang semakin meningkat setiap tahunnya seiring dengan perubahan luas panen yang juga meningkat. Hal ini menyebabkan adanya fluktuasi produktivitas padi sawah organik di Desa Pasar Terusan yang cenderung meningkat (BP3K Kecamatan Muara Bulian, 2014).

Pada tahun 2014 kelompok tani yang tetap mengusahakan padi sawah secara organik hanya 3 kelompok tani, yaitu Payo Kering I, Payo Kering II, dan Sumber Rezeki. 3 (tiga) kelompok tani tersebut memanfaatkan luas lahan panen seluas 436 hektar, dengan tingkat produksi sebesar 2.997 ton dengan tingkat produktivitas 6,86 ton/ha. Kelompok tani Sumber Rezeki memiliki produksi yang tertinggi yaitu sebesar 1.562 tondan memiliki luas panen 225 hektar dengan produktivitas 6,94 ton/ha (BP3K Kecamatan Muara Bulian, 2014).

Berhasil tidaknya seorang petani dalam memperoleh keuntungan pada usahatani padi sawah organik tidak terlepas dari berapa jumlah produksi persatuan luas pada satu musim tanam. Tingkat harga masing-masing sarana produksi akan mempengaruhi pertimbangan petani untuk menentukan jumlah faktor produksi yang akan digunakan selama proses produksi pada akhirnya akan sangat menentukan berapa besarnya keuntungan usahatani padi sawah organik yang akan diperoleh petani.

Produksi padi sawah organik yang dihasilkan secara tidak langsung memberikan kontribusi yang besar terhadap pendapatan petani di Desa Pasar Terusan. Hal ini dikarenakan lahan sawah di desa tersebut memiliki kesesuaian dengan syarat tumbuh tanaman padi sawah secara organik, sehingga memiliki potensi yang sangat tinggi untuk diusahakan di Desa Pasar Terusan. Walaupun ada beberapa komoditas unggulan dari sub sektor perkebunan, peternakan, dan hortikultura, namun hampir seluruh 
masyarakat di desa ini mengusahakan padi sawah organik sebagai komoditas utama usahataninya.

Petani sebagai pelaksana mengharap produksi yang lebih besar lagi agar memperoleh pendapatan yang besar pula. Petani menggunakan tenaga, modal dan sarana produksinya sebagai umpan untuk mendapatkan produksi yang diharapkan. Suatu usahatani dikatakan berhasil apabila usahatani tersebut dapat memenuhi kewajiban membayar bunga modal, alat yang digunakan, upah tenaga luar serta sarana produksi lainnya (Suratiyah, 2011).

Berdasarkan latar belakang dan permasalahan yang dikemukakan, maka penelitian ini bertujuan untuk mengetahui (1) besarnya keuntungan yang diperoleh petani dari usahatani padi sawah organik di Desa Pasar Terusan Kecamatan Muara Bulian Kabupaten Batang Hari (2) faktor-faktor yang mempengaruhi keuntungan usahatani padi sawah organik di Desa Pasar Terusan Kecamatan Muara Bulian Kabupaten Batang Hari.

\section{METODE PENELITIAN}

Penelitian ini merupakan studi kasus yang dilaksanakan di Desa Pasar Terusan Kecamatan Muara Bulian Kabupaten Batang Hari. Pemilihan desa ini dilakukan secara sengaja (purposive) dengan pertimbangan bahwa memiliki lahan yang cukup luas dan merupakan desa yang mengusahakan padi sawah organik. Petani yang menjadi objek penelitian ini adalah petani padi sawah organik di Desa Pasar Terusan Kecamatan Muara Bulian yang sudah menghasilkan. Penelitian ini dilaksanakan pada tanggal 01 Oktober 2015 sampai dengan 01 November 2015.

Besarnya sampel yang akan diambil adalah sebesar 10\% dari 3 kelompok tani yang mengusahakan padi sawah organik. Diketahui bahwa jumlah petani petani padi sawah organik adalah 445 petani yang terdiri dari 3 kelompok tani. Untuk kelompok tani Payo Kering I berjumlah 87 diambil 10\% sehingga di dapat sampel 9 petani, untuk kelompok tani Payo Kering II berjumlah 183 petani diambil 10\% di dapat sampel 18 petani, dan untuk kelompok tani Sumber Rezeki berjumlah 175 petani diambil 10\% di dapat sampel 18 petani. Sehingga jumlah sampel adalah sebanyak 45 petani. Ini sesuai dengan pendapat Singarimbun (1995), yang menyatakan bahwa dalam suatu penelitian yang menggunakan metode survei tidaklah perlu untuk meneliti populasi secara keseluruhan, karena selain membutuhkan biaya yang cukup besar juga membutuhkan waktu yang lama dan makin seragam populasi, maka makin kecil sampel yang dapat diambil.

Metode analisis yang digunakan dalam penelitian ini adalah analisis deskriptif kuantitatif, yaitu analisis pendapatan dan analisis regresi linier berganda. Untuk tujuan yang pertama yaitu untuk mengetahui besarnya keuntunganyang terdiri dari peneriman dan biaya produksi untuk usahatani padi sawah organik. Dimana struktur biaya yang dimaksudkan dalam penelitian ini adalah pengelompokan biaya dalam biaya tetap dan biaya tidak tetap. Mengukur dan menilai keuntungan usahatani padi sawah organik menggunakan rumus Suratiyah (2011):

$\pi=\mathrm{TR}-\mathrm{TC}$

Dimana:

$\pi=$ Keuntungan Usahatani $(\mathrm{Rp})$

$\mathrm{TR}=$ Total Penerimaan $(\mathrm{Rp})$

$\mathrm{TC}=$ Total Pengeluaran $(\mathrm{Rp})$

Menurut Soekartawi (1990) untuk menganalisis faktor-faktor yang mempengaruhi keuntungan usahatani padi sawah organik digunakan analisis regresi linier berganda 
(multiple regresion) dengan menggunakan fungsi keuntungan dalam bentukUnit Output Price sebagai berikut:

$\ln \pi^{*}=\operatorname{In} A^{*}+\beta_{1} \ln X_{1}+\beta_{2} \ln X_{2}+\beta_{3} \ln X_{3}+\beta_{4} \ln X_{4}+\beta_{5} \ln X_{5}+u$

Dimana :

$\ln \pi^{*}=$ Keuntungan usahatani padi organik yang "dinormalkan" (dibagi dengan harga produksi).

In $\mathrm{A}=$ Intercept

$\ln \mathrm{X}_{1}=$ Luas lahan (ha)

$\ln X_{2}=$ Biaya benih yang "dinormalkan" dengan harga produksi (Rp)

$\ln \mathrm{X}_{3}$ = Biaya pupuk yang "dinormalkan" dengan harga produksi (Rp)

$\ln \mathrm{X}_{4}$ = Biaya obat-obatan yang "dinormalkan" dengan harga produksi (Rp)

In $\mathrm{X}_{5}=$ Biaya Tenaga Kerja yang "dinormalkan" dengan harga produksi (Rp)

$\mathrm{U}=$ Kesalahan

$\beta_{1}-\beta_{5}=$ Parameter variabel penduga

Untuk mengetahui besarnya persentase sumbangan setiap variabel terhadap variasi apakah hasil pendugaan bidang regresi tersebut cukup baik atau tidak, digunakan ukuran koefisien determinasi $\left(\mathrm{R}^{2}\right)$ yang dapat diukur dengan rumus sebagai berikut :

Dimana :

$$
R^{2}=\frac{b_{i} Y_{i} X_{i}}{\sum Y_{\mathrm{i}}^{2}}
$$

$R^{2} \quad$ : Koefisien determinasi berganda

$X_{i} \quad$ : Jumlah variabel deviasi ke -i dari nilai rata-rata $\left(X_{i}-X\right)$

$Y_{i} \quad$ : Jumlah simpangan suatu variabel dari nilai rata-rata $\left(Y_{i}-Y\right)$

$b_{1} \quad$ :Koefisien variabel ke-i

$Y_{i}^{2} \quad$ : Kuadrat simpangan suatu variabel ke-i dari nilai rata-rata $\left(Y_{i}-Y\right)^{2}$

Nilai $R^{2}$ berkisar antara 0 dan 1 yaitu $0 \leq R^{2} \leq 1$. Makin mendekati 1 nilai $R^{2}$ berarti semakin kuat hubungan yang terdapat antara variabel terikat dengan variabel bebas. Untuk melihat apakah masing-masing koefisien signifikan atau tidak maka dilakukan dengan menggunakan alat uji hipotesis $F$ statistik dan $t$ statistik.

Uji $F$ statistik, uji ini dimaksudkan untuk mengetahui signifikan pengaruh variabel independent terhadap variabel dependent secara bersama (over all).

Nilai $F$ hitung diperoleh dengan rumus :

$F=\frac{R^{2} /(k-1)}{\left(1-R^{2}\right) / n-k}$

Dimana :

$R^{2}=$ Koefisiendeterminasi

$k$ = Banyaknya peubah bebas

$n$ = Banyaknya sampel

Nilai $F$ hitung yang didapat selanjutnya dibandingakan dengan nilai $F$ tabel pada derajat kebebasan (df) tertentu dengan tingkat keyakinan tertentu dengan keputusan sebagai berikut :

$F_{\text {hitung }}>F_{\text {tabel }} \longrightarrow$ Ho ditolak

$F_{\text {hitung }} \leq F_{\text {tabel }} \longrightarrow$ Ho diterima 
Hipotesis yang akan diuji :

Ho : tidak ada pengaruh variabel luas lahan, biaya benih, biaya pupuk, biaya obatobatan, dan biaya tenaga kerja terhadap keuntungan usahatani padi sawah organik.

$\mathrm{H}_{1}$ : ada pengaruh variabel luas lahan, biaya benih, biaya pupuk, biaya obat-obatan, dan biaya tenaga kerja terhadap keuntungan usahatani padi sawah organik.

Uji $t$ statistik dimaksudkan untuk mengetahui seberapa besar pengaruh tingkat signifikan variabel independent terhadap variabel dependent secara parsial atau sendirisendiri. Nilai $t$ hitung dapat diperoleh dengan rumus sebagai berikut :

$t=\frac{b}{S e\left(b^{2}\right)}$

Dimana :

$t \quad$ : t hitung

$b \quad$ : Koefisien regresi hasil estimasi

Se : Simpangan baku atau standar error

Nilai $t$ hitung yang didapat selanjutnya dibandingkan dengan nilai $t$ tabel pada derajat kebebasan (df) tertentu dengan tingkat keyakinan tertentu dengan keputusan sebagai berikut:

$t_{\text {hitung }}>t_{\text {tabel }} \longrightarrow$ Ho diterima

$t_{\text {hitung }} \leq t_{\text {tabel }} \longrightarrow$ Ho ditolak

\section{HASIL DAN PEMBAHASAN}

Desa Pasar Terusan merupakan salah satu dari 20 kelurahan atau desa yang ada di Kecamatan Muara Bulian Kabupaten Batang Hari. Desa Pasar Terusan terdiri dari 7 dusun dan 14 RT. Jarak Desa Pasar Terusan ke Ibu Kota Kecamatan adalah 17 km.lbu Kota Kecamatan Muara Bulian terletak di Kota Muara Bulian. Secara umum keadaan topografi Desa Pasar Terusan adalah merupakan daerah dataran rendah dengan memiliki daerah persawahan dan dan perkebunan dengan iklim tropis.

Desa Pasar Terusan memiliki batas wilayah sebagai berikut :

a. Sebelah utara berbatasan dengan Desa Rantau Kapas Tuo

b. Sebalah selatan berbatasan dengan Desa Simpang Terusan.

c. Sebelah barat berbatasan dengan Kecamatan Tembesi.

d. Sebelah timur berbatasan dengan Kecamatan Maro Sebo llir.

Usahatani padi sawah organik memerlukan biaya yang terbagi dalam dua bagian yaitu biaya tetap (fix cost) dan biaya variabel (variable cost). Biaya tetapadalah biaya yang relatif tetap jumlahnya dan terus dikeluarkan walaupun produksi yang diperoleh banyak atau sedikit, yang tergolong biaya tetap dalam penelitian ini adalah biaya penyusutan alat. Biaya penyusutan alat dalam penelitian ini adalah biaya yang sudah dalam pengurangan nilai dimana harga beli dikurangi nilai sisa kemudian di bagi dengan jumlah tahun penggunaan alat tersebut atau sejumlah uang yang dikeluarkan petani untuk membeli alat-alat usahatani yang digunakan dalam waktu yang relatif lama. Biaya variabel(variabel cost) yaitu biaya yang dikeluarkan selama proses produksi berlangsung. Adapunbiaya variabel dalam penelitian ini meliputi biaya benih, pupuk, obat-obatan dan 
biaya tenaga kerja (tenaga kerja dalam keluarga dan luar keluarga), serta biaya sewa lahan.

Luas lahan usahatani adalah luas lahan garapan yang dikelola petani dan yang dimiliki oleh petani yang dimiliki oleh petani serta keluarganya yang dinyatakan dalam satuan hektar. Menurut Mubyarto (1989) luas lahan garapan berpengaruh terhadap petani dalam mengadopsi teknik dan teknologi budidaya, dimana petani yang memiliki luas lahan yang sempit cenderung berusaha meningkatkan produktivitasnya dengan menggunakan teknik dan teknologi baru. Adapun rata-rata Luas lahan di daerah penelitian seluas 0,78 hektar.

Produksi padi sawah organik yang dimaksud dalam penelitian ini adalah produksi fisik berupa gabah kering giling dalam bentuk kilogram yang diperoleh petani dari hasil panen tanaman padi. Tanaman yang dipanen adalah bulir padi yang telah matang sesuai dengan kriteria tingkat kematangan bulir padi. Di daerah penelitian, jumlah produksi gabah kering giling masing-masing petani sampel bervariasi, produksi terendah adalah $5.071 \mathrm{~kg} / \mathrm{ha} /$ tahun dan produksi tertinggi adalah $6.250 \mathrm{~kg} / \mathrm{ha} /$ tahun dengan rata-rata produksi petani sampel di daerah penelitian adalah 5981,12 kg/ha/tahun.Sedangkan rata-rata produksi padi sawah organik per musim tanam adalah sebesar 4.675/kg.

Tabel 1. Komponen Rata-rata Biaya Usahatani Padi Sawah Organik di Desa Pasar Terusan Kecamatan Muara Bulian Kabupaten Batang Hari Tahun 2014

\begin{tabular}{lcc}
\hline \multicolumn{1}{c}{ Uraian } & Biaya (Rp/MT) & Biaya (Rp/Ha/Tahun) \\
\hline 1. Biaya Tetap & & \\
a. Biaya Penyusutan & 40.928 & $40.927,78$ \\
b. Biaya Sewa Lahan & 783.333 & 1.000 .000 \\
2. Biaya Variabel & & \\
a. Benih & 112.267 & 143.812 \\
b.Pupuk & 290.089 & 388.679 \\
c. Obat-obatan & 344.300 & 426.097 \\
d. TK. Dalam Keluarga & 2.705 .667 & 3.439 .658 \\
e. TK. Luar Keluarga & 2.074 .500 & 2.283 .881 \\
\hline Total Biaya & $\mathbf{6 . 3 5 1 . 0 8 3}$ & $\mathbf{7 . 7 2 3 . 0 5 5}$
\end{tabular}

Sumber : Hasil Olahan Data Primer Tahun 2015

Berdasarkan Tabel 1 dapat dilihat bahwa rata-rata biaya yang terbesar pada usahatani padi sawah organik pada biaya variabel yaitu pada biaya tenaga kerja dalam keluarga dan rata-rata biaya yang terkecil pada biaya tetap yaitu biaya penyusutan alat, baik pada biaya per musim tanam dan biaya per hektar. Adapun rata-rata total biaya usahatani padi sawah organik adalah sebesar Rp.6.351.083/musim tanam. Sedangkan rata-rata total biaya per hektar adalah sebesar Rp. 7.723.055/ha/tahun.

Tabel 2. Distribusi Penerimaan Petani Padi Sawah Organik di Desa Pasar Terusan Kecamatan Muara Bulian Kabupaten Batang Hari Tahun 2014

\begin{tabular}{cccc}
\hline No & Penerimaan (Rp) & Frekuensi & Persentase (\%) \\
\hline 1 & $25.357 .143-26.190 .476$ & 1 & 2,2 \\
2 & $26.190 .476-27.023 .810$ & 0 & 0 \\
3 & $27.023 .810-27.857 .144$ & 0 & 0 \\
4 & $27.857 .145-28.690 .478$ & 0 & 0 \\
5 & $28.690 .479-29.523 .812$ & 1 & 2,2 \\
6 & $29.523 .812-30.357 .146$ & 43 & 95,6 \\
\hline
\end{tabular}




\begin{tabular}{ccc}
\hline Jumlah & 45 & 100 \\
\hline
\end{tabular}

Sumber : Hasil Olahan Data Primer Tahun 2015

Pada Tabel 2 diatas menunjukkan bahwa penerimaan yang paling banyak pada petani padi sawah organik berkisar antara Rp. 25.357.143 sampai dengan Rp. 30.357.146 dari total keseluruhan sampel, sedangkan rata-rata penerimaan yang di terima petani sampel sebesar Rp. 29.905.624,27/ha/tahun.

Keuntungan usahatani padi sawah organik dalam penelitian ini adalah keuntungan petani yang hanya berasal dari usahatani padi sawah organik. Dalam penelitian ini keuntungan yang dihitung yaitu yang di peroleh dari penerimaan dikurangi dengan total biaya (biaya tetap dan biaya variabel). Biaya tetap meliputi penyusutan alat dan sewa lahan, sedangkan biaya variabel meliputi biaya benih, biaya pupuk, biaya obat-obatan, dan biaya tenaga kerja (luar keluarga dan dalam keluarga).

Tabel 3. Total Rata-rata Biaya dan Keuntungan Usahatani Padi Sawah Organik di Desa Pasar Terusan Kecamatan Muara Bulian Kabupaten Batang Hari Tahun 2014

\begin{tabular}{clcc}
\hline No & \multicolumn{1}{c}{ Uraian } & Biaya (Rp/MT) & Biaya (Rp/Ha/Tahun) \\
\hline 1 & Biaya Produksi & 40.928 & \\
& . Penyusutan Alat & 783.333 & $40.927,78$ \\
& . Sewa Lahan & 112.267 & 1.000 .000 \\
& . Benih & 290.089 & 143.812 \\
& . Pupuk & 344.300 & 388.679 \\
& . Obat-obatan & 2.705 .667 & 426.097 \\
& . TK. D. Keluarga & 2.074 .500 & 3.439 .658 \\
& . TK. L Keluarga & 6.351 .084 & 2.283 .881 \\
3 & Total Biaya Produksi & 4.675 & 7.723 .055 \\
4 & Jumlah Produksi & 5.000 & 5.981 \\
5 & Harga & 23.374 .444 & 5.000 \\
6 & Penerimaan & 20.512 .360 & 29.905 .624 \\
7 & Keuntungan & 17.023 .361 & 26.622 .227 \\
\hline
\end{tabular}

Sumber : Hasil Olahan Data Primer Tahun 2015

Berdasarkan Tabel 3dapat dilihat bahwa rata-rata penerimaan petani dari usahatani padi sawah organik sebesar Rp.29.905.624/musim tanam, sedangkan ratarata penerimaan per tahunnya sebesar Rp. 29.905.624/ha/tahun. Biaya total rata-rata pembiayaan secara ekonomi diperhitungkan sebesar 6.351.084/musim tanam dan ratarata total biaya per tahunnya sebesar Rp. 7.723.055/ha/tahun. sehingga di peroleh ratarata keuntungannya sebesar Rp. 17.023.361/musim tanam dan rata-rata keuntungan per tahunnya sebesar 22.182.569/ha/tahun.

Untuk mengetahui faktor-faktor yang dapat mempengaruhi keuntungan usahatani padi sawah organik, analisis selanjutnya dilakukan dengan Regresi Linier Berganda (Eviews 7). Dalam penelitian faktor-faktor yang di duga dapat mempengaruhi keuntungan usahatani padi sawah organik adalah luas lahan, biaya benih, biaya pupuk, biaya obat-obatan, dan biaya tenaga kerja.Hasil analisis terhadap fungsi keuntungan UOP dapat dilihat pada tabel 4. 
Tabel 4. Pengaruh Faktor-Faktor Keuntungan pada Usahatani Padi Sawah Organik pada Musim Tanam 2014.

\begin{tabular}{rrrrr}
\hline \hline Variable & Coefficient & Std. Error & t-Statistic & Prob. \\
\hline \hline LNX1 & 0.877490 & 0.099726 & 8.798980 & 0.0000 \\
LNX2 & 0.408357 & 0.091434 & 4.466158 & 0.0001 \\
LNX3 & -0.022199 & 0.012487 & -1.777820 & 0.0832 \\
LNX4 & -0.089063 & 0.034407 & -2.588514 & 0.0135 \\
LNX5 & -0.213774 & 0.023831 & -8.970404 & 0.0000 \\
\multicolumn{1}{c}{ C } & 4.352014 & 0.184396 & 23.60143 & 0.0000 \\
\hline \hline R-squared & 0.991452 & Mean dependent var & & 8.090362 \\
Adjusted R-squared & 0.990356 & S.D. dependent var & & 0.276346 \\
S.E. of regression & 0.027138 & Akaike info criterion & & -4.252207 \\
Sum squared resid & 0.028722 & Schwarz criterion & & -4.011318 \\
Log likelihood & 101.6746 & Hannan-Quinn criter. & & -4.162406 \\
F-statistic & 904.7106 & Durbin-Watson stat & & 2.313451 \\
Prob(F-statistic) & 0.000000 & & \\
\hline
\end{tabular}

Pada Tabel 4 menunjukkan bahwa hasil analisis sidik ragam diperoleh $\mathrm{F}_{\text {hitung }}$ sebesar 904.7106 dan $\mathrm{F}_{\text {Tabel }}$ sebesar 2,46 pada taraf 99 \% (Prob F- Static 0,0000). Hal ini berarti model penduga digunakan memiliki akurasi (kehandalan yang sangat nyata). Model hasil pendugaan jika dipergunakan untuk melakukan pendugaan pengaruh luas lahan, benih, pupuk, obat-obatan dan tenaga kerja akan dapat menjelaskan secara nyata terhadap variasi tinggi rendahnya keuntungan padi sawah organik.

Berdasarkan analisis regresi diperoleh nilai koefisien determinasi (Adjusted Rsquared) sebesar 0,99035. Nilai tersebut mengartikan bahwa 99,03\% variasi dependen (keuntungan) mampu dijelaskan secara bersama-sama oleh variabel independen (luas lahan, biaya benih, biaya pupuk, biaya obat-obatan, dan biaya tenaga kerja) yang dimasukkan kedalam persamaan pada tingkat kepercayaan $95 \%$. Sedangkan sisanya $0,97 \%$ disebabkan oleh pengaruh lainnya.

Berdasarkan Tabel 4 maka bentuk hubungan matematis fungsi keuntungan usahatani padi sawah organik di daerah penelitian dituliskan sebagai berikut:

$\operatorname{Ln} \pi=4,352+0,877 \operatorname{Ln} X_{1}+0,408 \operatorname{Ln} X_{2}-0,022 \operatorname{Ln} X_{3}-0,089 \operatorname{Ln} X_{4}-0,213 \operatorname{Ln} X_{5}$

Atau

$Y=4,352 X_{1}^{0,877} \cdot X_{2}^{0,408} \cdot X_{3}^{0,022} \cdot X_{4}^{0,089} \cdot X_{5}^{0,213}$

Dalam persamaan ini dapat dihitung bahwa besarnya $\sum b i=0,96<1$. Hal ini berarti skala produksi berada pada Increasing Return To Scale (IRRS dalam kurva fungsi produksi) dengan kata lain setiap penambahan input sebesar $10 \%$ akan meningkatkan produksi sebesar $9,6 \%$ hal ini menandakan rasional atau efisien secara ekonomi.

Untuk lebih mengetahui pengaruh luas lahan $\left(X_{1}\right)$, biaya benih $\left(X_{2}\right)$, biaya pupuk $\left(X_{3}\right)$, biaya obat-obatan (X4) dan biaya tenaga kerja (X5) secara individu, dapat dilihat pada interpretasi atau uraian dengan menggunakan uji t-hitung dan t-tabel sebagai berikut :

\section{Pengaruh Luas Lahan $\left(X_{1}\right)$ Terhadap Keuntungan Usahatani Padi Sawah Organik}

Berdasarkan hasil regresi linier berganda dapat ditentukan bahwa variabel luas lahan $\left(X_{1}\right)$ mempunyai koefisien sebesar 0,877 yang mempunyai pengaruh positif, artinya apabila terjadi penambahan luas lahan sebesar $10 \%$ maka akan meningkatkan keuntungan petani 
sebesar 8,77\% dengan asumsi faktor lain dianggap tetap. Hal ini sesuai dengan teori menurut Suratiyah (2011) yang menyatakan bahwa dipandang dari sudut efisiensi, semakin luas lahan yang diusahakan maka semakin tinggi produksi dan pendapatan per kesatuan luasnya.

Taraf signifikansi luas lahan $\left(\mathrm{X}_{1}\right)$ sebesar 0,033 lebih kecil dari 0,05 yang artinya signifikan secara statistik terhadap keuntungan petani. Dengan menggunakan uji statistik, variabel luas lahan mempunyai nilai t-hitung sebesar 8,798 lebih besar dari ttabel sebesar 2,022 (t-hitung > t-tabel), maka Ho ditolak $\mathrm{H}_{1}$ diterima, artinya bahwa variabel luas lahan $\left(X_{1}\right)$ berpengaruh nyata terhadap keuntungan usahatani padi sawah organik pada tingkat kepercayaan $95 \%$. Dari hasil tersebut menunjukkan bahwa penambahan luas lahan didaerah penelitian secara individu berpengaruh nyata terhadap keuntungan usahatani padi sawah organik.

Hal ini sejalan dengan penelitian Suprapto (2010), bahwa variabel luas lahan mempunyai pengaruh yang positif terhadap pendapatan, dimana koefisiennya menunjukkan sebesar 0,452 artinya apabila luas lahan bertambah $10 \%$ maka pendapatan petani padi organik bertambah sebesar $4,52 \%$ dan signifikan secara statistik terhadap pendapatan petani.

\section{Pengaruh Biaya Benih $\left(\mathbf{X}_{2}\right)$ Terhadap Keuntungan Usahatani Padi Sawah Organik}

Berdasarkan hasil regresi linier berganda dapat ditentukan bahwa variabel biaya benih $\left(X_{2}\right)$ mempunyai koefisien sebesar 0,408 yang mempunyai pengaruh positif, artinya apabila biaya benih bertambah $10 \%$, maka keuntungan petani padi sawah organik akan bertambah sebesar 4,08\%.

Taraf signifikansi biaya benih $\left(\mathrm{X}_{2}\right)$ sebesar 0,000 lebih kecil dari 0,05 yang artinya signifikan secara statistik terhadap keuntungan petani. Dengan menggunakan uji statistik, variabel biaya benih mempunyai nilai t-hitung sebesar 4,466 lebih besar dari ttabel sebesar 2,022 (t-hitung > t-tabel), maka Ho ditolak $\mathrm{H}_{1}$ diterima, artinya bahwa variabel biaya benih $\left(\mathrm{X}_{2}\right)$ berpengaruh nyata terhadap keuntungan usahatani padi sawah organik pada tingkat kepercayaan $95 \%$. Dari hasil tersebut menunjukkan bahwa penambahan jumlah benih didaerah penelitian secara individu berpengaruh nyata terhadap keuntungan usahatani padi sawah organik.

Variabel biaya benih berpengaruh nyata terhadap pendapatan petanipadi sawah organik karena adanya ketersediaan benih di daerah penelitian yang dilakukan setiap petani, hanya sebagian kecil petani membeli dengan petani yang lain. Adapun benih yang digunakan merupakan benih lokal yang telah beradaptasi dengan lahan setempat.

Hal ini tidak sejalan dengan penelitian Suprapto (2010), bahwa variabel biaya bibit dalam penelitian ini mempunyai pengaruh negatif namun tidak signifikan. Dengan bukti nilai t-hitung sebesar $-0,428$ lebih besar dari t-tabel sebesar 1,66 atau nilai probabilitas sebesar 0,670 lebih besar dari 0,05. Begitu juga dengan penelitian Zikrina (2012), bahwa variabel harga bibit memiliki nilaisignifikansi t sebesar 0,184. Nilai yang diperoleh lebih besar dari probabilitaskesalahan yang ditolerir, yaitu a 5\% atau 0,05. Hal ini menunjukkan bahwa Hoditerima atau $\mathrm{H} 1$ ditolak, yaitu variabel harga bibit secara parsial, tidakberpengaruh nyata terhadap variabel pendapatan petani padi organik.

\section{Pengaruh Biaya Pupuk $\left(X_{3}\right)$ Terhadap Keuntungan Usahatani Padi Sawah Organik}

Berdasarkan hasil regresi linier berganda dapat ditentukan bahwa variabel biaya pupuk $\left(X_{3}\right)$ mempunyai koefisien sebesar $-0,022$ yang mempunyai pengaruh negatif, artinya apabila biaya pupuk bertambah $10 \%$, maka keuntungan petani padi sawah organik akan berkurang sebesar $0,22 \%$.

Taraf signifikansi biaya pupuk $\left(\mathrm{X}_{3}\right)$ sebesar 0,083 lebih besar dari 0,05 yang artinya tidak signifikan secara statistik terhadap keuntungan petani. Dengan menggunakan uji 
statistik, variabel biaya pupuk mempunyai nilai t-hitung sebesar 1,777 lebih kecil dari ttabel sebesar 2,022 (t-hitung < $\mathrm{t}$-tabel), maka Ho diterima $\mathrm{H}_{1}$ ditolak, artinya bahwa variabel biaya pupuk $\left(\mathrm{X}_{3}\right)$ tidak berpengaruh nyata terhadap keuntungan usahatani padi sawah organik pada tingkat kepercayaan $95 \%$. Dari hasil tersebut menunjukkan bahwa penambahan jumlah pupuk didaerah penelitian secara individu tidak berpengaruh nyata terhadap keuntungan usahatani padi sawah organik.

Variabel biaya pupuk tidak berpengaruh nyata dikarenakan adanya peraturan Desa 6 (enam) bulan lepas dan 6 (enam) bulan tangkap sesuai dengan SK Turun ke Humo. Jadi selama dilepas ternak kerbau dimasukkan ke dalam areal sawah, sehingga secara tidak langsung kotoran ternak kerbau menjadi pupuk organik yang dapat menambah kesuburan tanah. Namun, dalam penelitian ini baiya pupuk yang dihitung yaitu biaya pupuk kandang ayam dan pupuk petroganik. Pupuk kandang ayam dapat dibeli didaerah setempat karena telah tersedia. Sedangkan pupuk petroorganik dapat dibeli di kelompok tani yang merupakan bantuan dari pemerintah dan harganya telah disubsidi oleh pemerintah.

Hal ini sejalan dengan penelitian Zikrina (2012), bahwa variabel harga pupuk kandang memilikinilai signifikansi t sebesar 0,950. Nilai yang diperoleh lebih besar dari probabilitaskesalahan yang ditolerir, yaitu $\alpha 5 \%$ atau 0,05 . Hal ini menunjukkan bahwa Hoditerima atau $\mathrm{H} 1$ ditolak, yaitu variabel harga pupuk kandang secara parsial,tidak berpengaruh nyata terhadap variabel pendapatan petani padi organik.Variabel harga pupuk kandang tidak berpengaruh nyata terhadappendapatan petani padi organik.

\section{Pengaruh Biaya Obat-obatan $\left(\mathrm{X}_{4}\right)$ Terhadap Keuntungan Usahatani Padi Sawah Organik}

Berdasarkan hasil regresi linier berganda dapat ditentukan bahwa variabel biaya obat-obatan $\left(\mathrm{X}_{4}\right)$ mempunyai koefisien sebesar -0,089 yang mempunyai pengaruh negatif, artinya apabila biaya obat-obatan bertambah $10 \%$, maka keuntungan petani padi sawah organik akan berkurang sebesar $0,89 \%$.

Taraf signifikansi biaya obat-obatan $\left(\mathrm{X}_{4}\right)$ sebesar 0,013 lebih kecil dari 0,05 yang artinya signifikan secara statistik terhadap keuntungan petani.Dengan menggunakan uji statistik, variabel biaya obat-obatan mempunyai nilai t-hitung sebesar 2,588 lebih besar dari t-tabel sebesar 2,022 (t-hitung < t-tabel), maka Ho ditolak $\mathrm{H}_{1}$ diterima, artinya bahwa variabel biaya obat-obatan $\left(\mathrm{X}_{4}\right)$ berpengaruh nyata terhadap keuntungan usahatani padi sawah organik pada tingkat kepercayaan $95 \%$. Dari hasil tersebut menunjukkan bahwa penambahan jumlah obat-obatan didaerah penelitian secara individu berpengaruh nyata terhadap keuntungan usahatani padi sawah organik.

Hal ini tidak sejalan dengan penelitian Zikrina (2012), bahwa variabel harga pestisida organik memiliki nilai signifikansi t sebesar 0,992 . Nilai yang diperoleh lebih besar dari probabilitas kesalahan yang ditolerir, yaitu $\alpha 5 \%$ atau 0,05 . Hal ini menunjukkan bahwa Ho diterima atau $\mathrm{H} 1$ ditolak, yaitu variabel pestisida organik secara parsial, tidak berpengaruh nyata terhadap variabel pendapatan petani padi organik.

\section{Pengaruh Biaya Tenaga Kerja $\left(X_{5}\right)$ Terhadap Keuntungan Usahatani Padi Sawah Organik}

Berdasarkan hasil regresi linier berganda dapat ditentukan bahwa variabel biaya tenaga kerja $\left(X_{5}\right)$ mempunyai koefisien sebesar $-0,213$ yang mempunyai pengaruh negatif, artinya apabila biaya tenaga kerja bertambah $10 \%$, maka keuntungan petani padi sawah organik akan berkurang sebesar $2,13 \%$.

Taraf signifikansi biaya tenaga kerja $\left(X_{5}\right)$ sebesar 0,000 lebih kecil dari 0,05 yang artinya signifikan secara statistik terhadap keuntungan petani.Dengan menggunakan uji statistik, variabel biaya tenaga kerja mempunyai nilai t-hitung sebesar 8,970 lebih besar 
dari t-tabel sebesar 2,022 (t-hitung > t-tabel), maka Ho ditolak $\mathrm{H}_{1}$ diterima, artinya bahwa variabel biaya tenaga kerja $\left(\mathrm{X}_{5}\right)$ berpengaruh nyata terhadap keuntungan usahatani padi sawah organik pada tingkat kepercayaan $95 \%$. Dari hasil tersebut menunjukkan bahwa penambahan curahan tenaga kerja didaerah penelitian secara individu berpengaruh nyata terhadap pendapatan usahatani padi sawah organik.

Upah tenaga kerja yang dikeluarkan petani sampel meliputi upah tenaga kerja dalam keluarga dan upah tenaga kerja luar keluarga. Adapun kegiatan yang dilakukan tenaga kerja tersebut yaitu persemaian, penanaman, penyiangan, pemupukan, pemberantasan hama, panen, dan pasca panen. Setiap petani sampel mengeluarkan biaya untuk upah tenaga kerja yang berbeda-beda. Semakin kecil upah tenaga kerja yang dikeluarkan maka semakin meningkat pendapatan petani padi sawah organik.

Hal ini sejalan dengan penelitian Zikrina (2012), bahwa variabel upah tenaga kerja memiliki nilai signifikansi $t$ sebesar 0,000 . Nilai yang diperoleh lebih kecil dari probabilitas kesalahan yang ditolerir, yaitu $\alpha 5 \%$ atau 0,05 . Hal ini menunjukkan bahwa Ho ditolak atau $\mathrm{H} 1$ diterima, yaitu variabel upah tenaga kerja secara parsial, berpengaruh nyata terhadap variabel pendapatan petani padi organik. Nilai koefisien regresi sebesar $-4,681$ menunjukkan bahwa setiap adanya peningkatan upah tenaga kerja sebesar Rp.1/orang/ha, maka terjadi penurunan pendapatan petani padi organik sebesar Rp.4.681 perhektar. Sebaliknya, jika terjadi penurunan upah tenaga kerja, akan menyebabkan kenaikan pendapatan petani padi organik.

\section{KESIMPULAN}

Dari hasil penelitian yang telah dilaksanakan, maka dapat ditarik kesimpulan bahwa rata-rata keuntungan yang diperoleh dari usahatani padi sawah organik adalah sebesar Rp.17.023.361/musim tanam dan untuk per hektarnya sebesar Rp.22.182.569/ha/tahun. Dari hasil penelitian dengan metode Regresi Linier Berganda diketahui bahwa faktor-faktor seperti luas lahan, biaya benih, dan biaya obat-obatan serta biaya tenaga kerja berpengaruh secara nyata sehingga baik untuk ditingkatkan. Sedangkan biaya pupuk tidak berpengaruh secara nyata karena penggunaannya telah melebihi pada kisaran yang optimal.

\section{UCAPAN TERIMAKASIH}

Penulis sampaikan Ucapan terimakasih kepada Dekan Fakultas Pertanian Universitas Jambi dan Ketua Program Studi Agribisnis Fakultas Pertanian Universitas Jambi yang telah memfasilitasi pelaksanaan penelitian ini. Ucapan terima kasih kepada Bapak Atiq selaku Kepala Desa Pasar Terusan Kecamatan Muara Bulian Kabupaten Batang Hari dan Ibu Lidia Febrina, S.Pt, MP selaku penyuluh Desa Pasar Terusan yang sangat membantu serta memberikan data bagi penulis sehingga penulis dapat menyelesaikan artikel ini.

\section{DAFTAR PUSTAKA}

Badan Pelaksana Penyuluhan Pertanian dan Kehutanan (BP3K). 2014. Data Kelompok Tani dan Data Produksi Tahun 2014. BP3K Kecamatan Muara Bulian. Muara Bulian.

Mubyarto. 1989. Pengantar Ekonomi Pertanian. LP3S. Jakarta. 
Santoso, K. N. 2012. Analisis Komparasi Usahatani Padi Organik dan Anorganik di Kecamatan Sambirejo Kabupaten Sragen. Skripsi Fakultas Pertanian dan Bisnis. Universitas Kristen Satya Wacana.

Singarimbun, 1995. Metode Penelitian Survey. LP3S. Jakarta.

Soekartawi. 1990. Teori Ekonomi Produksi dengan Pokok Bahasan Analisis Fungsi CobbDouglas. Rajawali Pers. Jakarta.

Suprapto. E. 2010. Analisis Faktor-Faktor yang Mempengaruhi Usahatani Padi Organik di Kabupaten Sragen. Tesis Fakultas Ekonomi. Program Pascasarjana Magister Ekonomi Dan Studi Pembangunan. Universitas Sebelas Maret.

Suratiyah, K. 2011. Ilmu Usahatani. Penebar Swadaya. Jakarta.

Sutanto. R. 2002. Pertanian Organik Menuju Pertanian Alternatif dan Berkelanjutan. Kanisius. Yogyakarta.

Tombe, M dan Hendra S. 2010. Bertani Organik dengan Teknologi Biofob. Lily Publisher. Yogyakarta.

Zikrina. 2012. Faktor-Faktor yang Mempengaruhi Pendapatan Petani Padi Organik di Kabupaten Sedang Berdagai. Jurnal Fakultas Pertanian. Universitas Sumatera Utara. 